\author{
Oskar Losy, Anna Podolska
}

\title{
The Principle of Mutual Trust in the Area of Freedom, Security and Justice. Analysis of Selected Case Law
}

\section{Introduction}

Since 1999, the European Union (EU) has been implementing the principle of mutual recognition (MR), which is referred to as the cornerstone of judicial cooperation in criminal matters. ${ }^{1}$ The principle of mutual recognition assumes that decisions of the judicial authorities of one Member State should as far as possible take effect automatically in all other Member States of the EU. ${ }^{2}$ Mutual recognition is based on a presumption of mutual trust. The logic is that "the extraterritoriality of judicial decisions, created by mutual recognition, will only be accepted if there is a sufficiently high level of mutual trust between Member States". 3

Mutual trust can therefore be regarded as a prerequisite for the principle of mutual recognition, or its 'twin brother'. Mutual trust, as an idea, was initially perceived as a political postulate. However, along with progress towards judicial cooperation in criminal matters it became a systemic principle, proclaimed not only as a cornerstone in the Area of Freedom, Security and Justice, but also as a catalyst for integration. ${ }^{4}$ There is no legal definition of 'mutual trust' and, as was aptly observed by T. Ostropolski, the term lacks an explicit normative basis. ${ }^{5}$ The meaning of the principle can be - at least partially recalled from treaties, texts of different legal instruments and policy documents. Conversely, the mutual recognition principle currently has a strong legal basis in EU law.

1 Presidency Conclusions, Tampere European Council 15 and 16 October 1999, http://www. europarl.europa.eu/summits/tam_en.htm [access: 17.01.2018].

2 For more on mutual recognition vid. for example: L. Klimek, Mutual recognition of Judicial Decisions in European Criminal Law, Bratislava 2017.

3 A. Willems, Mutual Trust as a term of art in EU Criminal Law: Revealing its hybrid character, in "European Journal of Legal Studies" 2016, vol. 9, p. 213.

4 Cf. judgment of the Polish Constitutional Court of 16 November 2011 in case no. SK 45/09.

5 T. Ostropolski, The CJEU as a Defender of Mutual Trust, in 'New Journal of European Criminal Law" 2015, vol. 6, p.166. 
The Treaty of Lisbon gave the principle of mutual recognition a pivotal role in the move towards judicial cooperation in criminal matters. ${ }^{6}$

The Council and the Commission have rather quickly revised their attitudes towards the factual level of trust between member states. The same could be said of the European Parliament, which opted for complex regulation of procedural rights to ensure at least a minimal level of common guarantees in Member States. Unlike the other EU Institutions, the Court of Justice of The European Union (CJEU) has become the most important advocate of mutual trust. The Court has upheld the presumption of trust and has become one of its strongest defenders. ${ }^{7}$ Reference to mutual trust was an important part of the Court's reasoning in many decisions. However, it can be noted that even the CJEU's case law in this regard has been far from uniform over the course of time.

In this article we will try to present how mutual trust is perceived by the EU Court and how this view has evolved. In addition, analysis of these judgments will be complemented by the views of the European Court of Human Rights (ECtHR) and the German Constitutional Court (Bundesverfassungsgericht, BVerfG). This will help in forming a certain concept for the interpretation of mutual trust by European courts acting on different jurisdiction levels.

\section{Mutual Trust as a Prerequisite for the Principle of Mutual Recognition}

Mutual recognition is not a new concept. The first attempt to introduce mutual recognition in the area of criminal law in Europe was seen in the Council of Europe's conventions adopted in the 1960s and 1970s. ${ }^{8}$ They proved to be unsuccessful, especially due to the lack of trust between states. At the EU level, mutual recognition was recognised as a cornerstone of judicial co-operation in criminal matters during the Tampere European Council in 1999. ${ }^{9}$ Just one year later, the European Commission stated that the traditional system of co-operation is not only slow, but also cumbersome, and sometimes it is quite uncertain what results a judge or prosecutor who makes a request will get. ${ }^{10}$ It argued

6 In accordance with art. 82(1) Treaty on the Functioning of the European Union: Judicial cooperation in criminal matters in the Union shall be based on the principle of mutual recognition of judgments and judicial decisions and shall include the approximation of the laws and regulations of the Member States.

7 T. Ostropolski, op. cit., p. 166.

8 For example: European Convention on the Punishment of Road Traffic Offences of 30 November 1964, European Treaty Series no. 052 [1964].

9 Presidency Conclusions, Tampere European Council 15 and 16 October 1999.

10 Communication from the Commission to the Council and the European Parliament - Mutual recognition of Final Decisions in criminal matters /* COM/2000/0495 final */, p. 2. 
that judicial co-operation might also benefit from the concept of mutual recognition. Then, the Commission introduced a Program of Measures to Implement the Principle of Mutual Recognition of Decisions in Criminal Matters. This document sheds light on the specific relationship between mutual recognition and mutual trust. It stipulates that: "Implementation of the principle of mutual recognition of decisions in criminal matters presupposes that Member States have trust in each other's' criminal justice systems. That trust is grounded, in particular, on their shared commitment to the principles of freedom, democracy and respect for human rights, fundamental freedoms and the rule of law". ${ }^{11}$ This begs the question of whether the presumption that Member States would trust each other was justified and rational. At that time, no measures aimed at mitigating the differences in the criminal legal systems of member states or approximate minimal procedural rights were envisaged in the treaties. Leaving this aside, it can be said that at the outset there was a strong belief that the level of trust between states - all of which were already parties to the European Convention on Human Rights (ECHR) - was high, which was reflected in the different instruments stipulated in secondary law.

Over time, the wording used to describe mutual trust in different MR instruments has changed significantly. This can be shown in the examples of different phrases used in MR instruments. The framework decision (FD) on the first, and so far most important, mutual recognition measure - the European Arrest Warrant (EAW $)^{12}$ declares that the level of confidence between Member States is high. ${ }^{13}$ However, in as early as 2008, in the FD on custodial sentences we read that mutual recognition 'should become the cornerstone' of cooperation and - rather oddly - that relations between Member States 'are characterised by special mutual confidence'. ${ }^{14}$ This change in tone might therefore reflect

11 Programme of measures to implement the principle of mutual recognition of decisions in criminal matters (Official Journal L C 12/10 of 15 January 2001).

12 Council Framework Decision 2002/584/JHA of 13 June 2002 on the European arrest warrant and the surrender procedures between Member States as amended by the Council Framework Decision 2009/299/JHA of 26 February 2009 amending by the Framework Decisions 2002/584/JHA, 2005/214/JHA, 2006/783/JHA, 2008/909/JHA and 2008/947/JHA, thereby enhancing the procedural rights of persons and fostering the application of the principle of mutual recognition to decisions rendered in the absence of the person concerned at the trial (Official Journal L 81/14 of 27 March 2009).

13 In accordance with recital 10 of FD EAW The mechanism of the European arrest warrant is based on a high level of confidence between Member States.

14 Council Framework Decision 2008/909/JHA of 27 November 2008 on the application of the principle of mutual recognition to judgments in criminal matters imposing custodial sentences or measures involving deprivation of liberty for the purpose of their enforcement in the European Union (Official Journal L 327/27 of 5 December 2008) as amended by Council Framework Decision 2009/299/JHA of 26 February 2009 amending by the Framework Decisions 2002/584/JHA, 2005/214/JHA, 2006/783/JHA, 2008/909/JHA and 2008/947/JHA, thereby enhancing the procedural rights of persons and fostering the application of the principle of mutual recognition to decisions rendered in the absence of the person concerned at the trial. 
the real level of trust between member states. As was rightly observed by A. Willems, ${ }^{15}$ examples of the effects of these doubts regarding foreign criminal proceedings are also visible in the most recent MR instruments. The 2014 FD on the European Investigation Order (EIO), ${ }^{16}$ explicitly acknowledges that the trust presumption is rebuttable and introduces for the first time the explicit 'human rights' refusal ground.

The growing scepticism towards mutual trust might stem from the first years' experiences of the EAW, the introduction of which has caused a lot of controversy. ${ }^{17}$ This has concerned, among other things, the partial abolition of dual criminality, which was challenged on the grounds that it breached the principle of legality and the principles of equality and non-discrimination. ${ }^{18}$ The most fundamental issue for the legitimacy of the EAW (and what could also be accurate for other MR instruments) is whether the MR system is compatible with human rights. Therefore, significant changes in the refusal grounds catalogue of the EIO (described above) are not a big surprise.

\section{The Case Law of the CJEU}

At the outset it should be noted that the jurisdiction of the CJEU with regard to cooperation in criminal matters was limited until 1st December 2014. ${ }^{19}$ After the Lisbon Treaty came into force there was a 5-year transition period concerning instruments adopted before the coming into force of the Lisbon Treaty. A significant amount of the case law of the CJEU was devoted to the EAW. ${ }^{20}$ The CJEU has underlined many times that the

15 Cf. A. Willems, op. cit. p. 219.

16 Directive 2014/41/EU of the European Parliament and of the Council of 3 April 2014 regarding the European investigation order in criminal matters (Official Journal L 130/1 of 1 May 2014).

17 See for example: E. Guild, L. Martin (Ed), Still not resolved? Constitutional Issues of the European Arrest Warrant: a Look at Challenges Ahead after the Lessons Learned from the Pasty, https:// www.utwente.n1/en/bms/pa/staff/marin/Still\%20not $\% 20$ resolved\%20Constitutional\%20 Challenges\%20to\%20the\%20European\%20Arrest\%20Warrant.pdf [access: 02.01.2018].

18 Case C-303/05 Advocaten voor de Wereld, ECLI:EU:C:2007:261.

19 See Article 10 (1) of Protocol 36 annexed to the Treaty of Lisbon (consolidated version Official Journal C 326/2001 of 26 October 2012).

20 Cf. cases: C-303/05 Advocaten voor de Wereld, ECLI:EU:C:2007:261; C-66/08 Koztowski, ECLI:EU:C:2008:437; C-296/08 PPU Santesteban Goicoechea, ECLI:EU:C:2008:457; C-388/08 PPU Leymann and Pustovarov, ECLI:EU:C:2008:669; C-123/08 Wolzenburg, ECLI:EU:C:2009:616; C-261/09 Mantello, ECLI:EU:C:2010:683; C-306/09 I.B., ECLI:EU:C:2010:626; C-192/12 PPU West, ECLI:EU:C:2012:404; C-42/11 Lopes da Silva Jorge, ECLI:EU:C:2012:517; C-396/11 Radu, ECLI:EU:C:2013:39; C-399/11 Melloni, ECLI:EU:C:2013:107; C-168/13 PPU F., ECLI:EU:C:2013:358; C-237/15 PPU Lanigan, ECLI:EU:C:2015:474; C-463/15 PPU A, ECLI:EU:C:2015:634; C-241/15 Bob-Dogi, ECLI:EU:C:2016:385. 
"EAW must be executed on the basis of the principle of mutual recognition and in accordance with the provisions of the framework decision". As S. Peers rightly observed, the case law of the CJEU "focuses overwhelmingly on the efficient application of the European Arrest Warrant", ${ }^{21}$ which, however, can also apply respectively to other mutual recognition instruments. As can be seen, even with regard to human rights objections, the core argument of the Court was that Member State have mutual trust in each other's criminal systems.

In the ground-breaking case Advocaten voor de Wereld, ${ }^{22}$ answering the allegation that (only) partial abolition of dual criminality with regard to 32 offences $^{23}$ breached the principles of equality and non-discrimination, the CJEU held that: "The Council was able to form the view, on the basis of the principle of mutual recognition and in the light of the high degree of trust and solidarity between the Member States, that, whether by reason of their inherent nature or by reason of the punishment (...), the categories of offences in question feature among those the seriousness of which in terms of adversely affecting public order and public safety justifies dispensing with the verification of double criminality". ${ }^{24}$

Already then, the argument that there was a high degree of trust and solidarity was an important part of the Court's reasoning. However, the judgments were criticised by many, who argued that "to a certain extent the impression prevails that the Court chose somewhat easy arguments to dispose of some rather difficult issues". ${ }^{25}$

Subsequently, in Gözütok and Brügge, ${ }^{26}$ the Court was asked whether the ne bis in idem principle covers the situation where criminal proceedings have been definitively discontinued due to a settlement before the prosecuting authority (without any involvement of the judge at that phase). The CJEU answered positively, which was met with the surprise of many Member States, as during the hearing it had argued the opposite. In a famous statement, the CJEU - referring to the principle of mutual trust - held the following: "There is a necessary implication that the Member States have mutual trust in their criminal justice systems and that each of them recognises the criminal law in force in the other Member States even when the outcome would be different if its own national law were applied".

21 S. Peers, EU Justice and Home Affairs Law: Volume II: EU Criminal Law, Policing, and Civil Law, Oxford 2016, p. 99.

22 Case C-303/05.

23 On partial abolition of double criminality requirement vid. more: Retbinking international cooperation in criminal matters. Moving beyond actors, bringing logic back, footed in reality, eds. G. Vermeulen, W. De Bondt ,C. Ryckman, Antwerp 2012.

24 Case C-303/05, § 57-58.

25 F. Geyer, European Arrest Warrant: Advocaten voor de Wereld VZW v. Leden van de Ministerraad, in: "European Constitutional Law Review" 2008, no. 4, p. 161.

26 Joined Cases C-187/01 and C-385/01 Gözütok and Brügge, ECLI:EU:C:2003:87. 
Further, in the ruling Melloni ${ }^{27}$ of 26 February 2014, the CJEU held that it is not permissible for Member States to have more rigorous rules as regards guarantees for the EAW following in absentia trials.

In this case, Mr Melloni - an Italian businessman prosecuted for bankruptcy fraud, was hiding behind the justice system in Spain. The trial took place in Italy (which Melloni was fully aware of) but the accused decided not to attend it personally. Still, during the entire trial, he was represented by defence lawyers. When the conviction became final in 2004, Italy issued an EAW ordering Spain to surrender Mr Melloni. It is worth noting here that under the Spanish Constitution, if a person has been convicted in his or her absence (in absentia), surrender to the execution of that conviction must be made conditional on the right to challenge the conviction. Such a right was not foreseen in Italian criminal proceedings when $\mathrm{Mr}$ Melloni was convicted. Not surprisingly therefore, Mr Melloni referred to the right to a fair trial envisaged in the Spanish Constitution. $\mathrm{He}$ argued that his surrender to Italy would violate Spanish Constitutional standards, since in Italy he could not count on a retrial. From the case law of the Spanish constitution it follows that the described rule also applies to situations where the accused was represented by lawyers. Therefore, personal appearance is an element of this entitlement to retrial. At the same time, EU law does not create an equivalent system of guarantees as in Spanish law. Article 4a(1) FD EAW ${ }^{28}$ allows the Executing State to refuse the surrender or to make it conditional on the right to a retrial in a limited number of situations. Mr Melloni's case would not fall into these exceptions since, in accordance with Art. 4a(1)(b) FD EAW, if the person convicted in his or her absence was defended and represented by a lawyer, the Executing State cannot refuse surrender. There was therefore a clear conflict between Spanish and EU law provisions. Given this fact, it should also be borne in mind that Art. 53 of the Charter of Fundamental Rights of the European Union (Charter) ${ }^{29}$ states that "nothing in this Charter shall be interpreted as restricting or adversely affecting human rights and fundamental freedoms as recognized (...) by Union law and international law (...), including the ECHR and by the Member States' constitutions". Does this mean, therefore, that referring to the Charter and its own constitutional provisions, Spain should refuse the surrender of Mr Melloni (at least until his right to challenge the in absentia conviction were to be guaranteed)? According to the CJEU, that interpretation of Article 53 of the Charter would undermine the principle of the primacy of EU law. It would allow a Member State to disapply EU legal rules which

27 Case C-399/11 and case C-237/15 PPU.

28 As amended by Council Framework Decision 2009/299/JHA of 26 February 2009 amending Framework Decisions 2002/584/JHA, 2005/214/JHA, 2006/783/JHA, 2008/909/JHA and 2008/947/JHA, thereby enhancing the procedural rights of persons and fostering the application of the principle of mutual recognition to decisions rendered in the absence of the person concerned at the trial.

29 Official Journal C 326/391 of 26 October 2012. 
are fully in compliance with the Charter, where they infringe the fundamental rights guaranteed by that State's constitution. The Court referred again to the principle of mutual trust end effectiveness of the EAW, stating that (...) "casting doubt on the uniformity of the standard of protection of fundamental rights (...), would undermine the principles of mutual trust and recognition would, therefore, compromise the efficacy of that framework decision". Therefore, the concept of mutual mutual trust stands behind an explanation of the rule that the Charter is to be used as a maximum standard of fundamental rights protection in EU criminal justice. ${ }^{30}$

Mutual trust arguments were a very important part of the CJEU's judgment on access of the EU to the European Convention on Human Rights, ${ }^{31}$ i.e. Opinion 2/13 of 18 December 2014, ${ }^{32}$ sometimes ironically called the 'Christmas bombshell'. ${ }^{33}$ In short, it might be stated that in the Opinion, the Court criticised (on many different levels) the draft of the accession agreement. It stated that the draft agreement contained many fundamental errors and was incompatible with the treaties.

One of the core arguments of the CJEU related to mutual trust issues. In the Court's opinion, the draft agreement may pose a danger to the autonomy of EU law because it may negatively affect the principle of mutual trust between Member States in the context of the respect for fundamental rights, which is particularly relevant in the Area of Freedom, Security and Justice. This danger stems from the obligation imposed on the Member States to check the observance of fundamental rights by all other party states even if they are EU Members. Such a requirement would impair the principle of mutual trust, as can be deduced from the following statement: "The principle of mutual trust between the Member States is of fundamental importance in EU law, given that it allows an area without internal borders to be created and maintained. That principle requires, particularly with regard to the area of freedom, security and justice, each of those States, save in exceptional circumstances, to consider all the other Member States to be complying with EU law and particularly with the fundamental rights recognised by EU law". ${ }^{34}$

30 Which does not preclude higher human rights standards in other EU law areas, cf. case C-617/10 Åkerberg Fransson, ECLI:EU:C:2013:105.

31 For more information on the complicated issue of accession, vid.: P. Gragl, The Accession of the European Union to the European Convention on Human Rights, Oxford and Portland 2013.

32 Opinion 2/13 of 18 December 2014 on Accession of the European Union to the European Convention for the Protection of Human Rights and Fundamental Freedoms, ECLI:EU:C:2014:2454.

33 Cf. S. Douglass-Scott, Opinion 2/13 on EU accession to the ECHR: a Christmas bombshell from the European Court of Justice, http://verfassungsblog.de/opinion-213-eu-accession-echr-christmasbombshell-european-court-justice-2/\#.VRGRofmG9uw [access: 11.01.2018].

34 Cf. Paragraph 191 of Opinion 2/13. 
The CJEU has repeated the arguments expressed in the Melloni case. The Court requires that the ECtHR effectively respects its jurisprudence and thereby gives supremacy to the primacy, unity and effectiveness of EU law over the protection of fundamental rights under the ECHR. ${ }^{35}$

As was presented above, the CJEU has consequently defended the principle of mutual trust. According to its judgments, mutual trust can be seen as a matter of 'fundamental importance' or as 'one of the key specificities of EU law'. ${ }^{36}$ Bearing this in mind, it should be emphasised, however, that the principle of mutual trust is not absolute, and even in the opinion of its biggest defender the mutual trust assumption can be rebutted.

In the 'asylum case' N.S. ${ }^{37}$ the Court held that EU law precludes a conclusive presumption that the Member State responsible under the Dublin Regulation ${ }^{38}$ observes fundamental rights. In this case, the court held that a Member State may not transfer an asylum seeker to another Member State (responsible under the Dublin regime) where there is a risk that asylum seekers would face a real risk of being subjected to inhuman or degrading treatment. Where the MS cannot be unaware of systemic deficiencies in the asylum procedure, both the presumption of mutual trust, and the presumption underlying the relevant legislation that asylum seekers will be treated in a way which complies with fundamental rights, must be regarded as rebuttable. ${ }^{39}$ The member state facing major operational problems in this case was Greece, which was severely affected by the migration crisis (the case concerned the period from 2008 to 2009). At that time in Greece there existed a systemic deficiency in the asylum procedure and in the reception conditions for asylum seekers. It is assumed that Member States participating in the Common European Asylum System observe fundamental rights, including the rights based on the Geneva Convention, and on the ECHR, and that the Member States can have confidence in each other in that regard. However, when it is evident (for example on the basis of ECtHR jurisprudence) ${ }^{40}$ that a given member state (or a third country) infringes the fundamental rights of the asylum seeker, such confidence is unfounded. Moreover, infringement of fundamental rights by the Member State responsible will not

35 Cf. S. Reitemeyer, B. Pirker, Opinion 2/13 of the court of justice on access of the EU to the ECHR one step ahead and two steps back, http://europeanlawblog.eu/2015/03/31/opinion-213-of-thecourt-of-justice-on-access-of-the-eu-to-the-echr-one-step-ahead-and-two-steps-back/ [access: 21.12.2017].

36 T. Ostropolski, op. cit., p.166.

37 Joined Cases C-411/10 and C-493/10 N.S. and others, ECLI:EU:C:2011:865.

38 Council Regulation (EC) No 343/2003 of 18 February 2003 establishing the criteria and mechanisms for determining the Member State responsible for examining an asylum application lodged in one of the Member States by a third-country national (Official Journal L 50/1 of 25 February 2003).

39 Paragraph 104 of Joined Cases C-411/10 and C-493/10 N.S. and others.

40 In this regard vid. also the judgment of the ECtHR of 21 January 2011 in the case MSS v Belgium and Greece, (no. 30696/09). 
affect the obligations stemming from, among others, the Dublin Regulation of the other states. The Court clearly stated that if there are substantial grounds for believing that there are systemic flaws in the asylum procedure and reception conditions for asylum applicants in the Member State responsible, resulting in inhuman or degrading treatment, the transfer would be incompatible with Art. 4 of the Charter (Prohibition of torture and inhuman or degrading treatment or punishment). Thus, if compliance with fundamental rights requires the Member State where the asylum seeker is present to examine the asylum application, that Member State has no choice but to do so. ${ }^{41}$

According to Mitsilegas, the N.S. judgment "constitutes a turning point in the evolution of inter-state cooperation in the Area of Freedom, Security and Justice, and signifies the end of automaticity in inter-state cooperation not only as regards the Dublin Regulation, but also as regards cooperative systems in the fields of criminal law and civil law". ${ }^{42}$ In turn, S. Peers asks whether this judgment means 'the death of mutual trust' ${ }^{43}$ Probably not, but after this judgment one surely cannot automatically rely on the 'mutual trust' that other Member States will observe human rights and that, simply because they are a part of the EU, they should always unconditionally be treated as 'safe'.

Another occasion where the CJEU confirmed that the assumption of mutual trust has certain limits was its judgment in the already well-described case Aranyosi and Căldăraru. ${ }^{44}$ This case concerned detention conditions in a state that issues the EAW. In the cases of Mr Aranyosi and Mr Căldăraru, the German court asked the CJEU whether it should execute an EAW despite the concerns raised by the fugitives about prison conditions in Hungary and Romania which had led to ECtHR rulings finding violations of Article $3 \mathrm{ECHR}$ (freedom from torture or other inhuman or degrading treatment or punishment). It was a general assumption for all instruments existing in judicial cooperation in criminal matters that Mutual recognition should ensure not only that sentences are enforced, but also that they will be served in a way that protects individual

$41 \mathrm{Cf}$. K. Lenaerts, The principle of mutual recognition in the area of freedom, security and justice, the fourth annual lecture at All Souls College, University of Oxford, 30 January 2015, https://www. law.ox.ac.uk/sites/files/oxlaw/the_principle_of_mutual_recognition_in_the_area_of_freedom_judge_lenaerts.pdf [access: 22.12.2017].

42 V. Mitsilegas, The Limits of Mutual Trust in Europe's Area of Freedom, Security and Justice: From Automatic Inter-State Cooperation to the Slow Emergence of the Individual, "Yearbook of European Law”2012, no. 31 ,p. 358.

43 S. Peers, Court of Justice: The NS and ME Opinions - The Death of "Mutual Trust"?, http://oppenheimer.mcgill.ca/IMG/pdf/Court_of_Justice-_The_NS_and_ME_Opinions_-_The_Death_ of_Mutual_Trust_.pdf [access: 15.12.2017].

44 Joined Cases C-404/15 and C-659/15 PPU, Aranyosi and Căldăraru, ECLI:EU:C:2016:198; Cf. S. Gáspár-Szilágyi, Joined Cases Aranyosi and Căldăraru: Converging Human Rights Standards, Mutual Trust and a New Ground for Postponing a European Arrest Warrant, "European Journal of Crime, Criminal Law and Criminal Justice” 2016, vol. 24, no. 2-3. 
rights. ${ }^{45}$ At the same time, however, the CJEU has so far highlighted that the list of refusal grounds is exhaustive and that refusal on general a human-rights based exception would undermine the effectiveness of the EAW system. However, these arguments seemed insufficient in this case. After the ECtHR's judgments ${ }^{46}$ it was obvious that prisons in Romania and Hungary were dramatically overcrowded and that the executions of the EAW in these circumstances would not be defensible from the perspective of human rights protection. The CJEU had to consider whether in such cases judicial authority may or must refuse execution of the EAW, or whether it may or must make the surrender of that person conditional on obtaining information that detention conditions are compatible with fundamental rights.

At the beginning of the reasoning, the Court repeated that the list of refusal grounds is exhaustive and that an EAW may be made subject to only one of the conditions exhaustively laid down in Article 5 of that Framework Decision. Again - according to the Court - this is justified by the high level of trust between member states. The Court, therefore, did not change its approach and did not accept that in certain circumstances fundamental rights violations should be treated as an additional ground for refusal or non-execution. ${ }^{47} \mathrm{In}$ its opinion, the mere finding that there is a real risk of inhuman or degrading treatment by virtue of the general conditions of detention in the issuing Member State cannot lead, in itself, to the refusal to execute a European arrest warrant. However, the Court stated that "limitations of the principles of mutual recognition and mutual trust between Member States can be made in exceptional circumstances". ${ }^{48}$ As to the merits, the Court held that if there is "a real risk of inhuman or degrading treatment, the execution of the warrant must be postponed but it cannot be abandoned". Before that, however, the executing judicial authority must go through the specific 'two-tier test'.

First, it must check whether there is a systemic failure to ensure decent prison conditions in a given State and second - a 'real risk' that the individual fugitive would be subject to such conditions if the EAW is executed. If these 'conditions' are met, the executing State's authorities have to postpone execution of the EAW until the detention conditions in the issuing State have improved.

This case is another example where mutual trust cannot be achieved by a mere decision or legislation. The CJEU tried to find a compromise between the effectiveness and integrity of the EAW and the need for human rights protection. This judgment,

45 Communication from the Commission to the Council and the European Parliament - Mutual recognition of Final Decisions in criminal matters, p. 2.

46 Cf. e.g. judgment of ECtHR of 10 March 2015 in the case Varga and Others v. Hungary, (Nos 14097/12, 45135/12, 73712/12, 34001/13, 44055/13 and 64586/13).

47 Excellent considerations on this issue can be found in: opinion of Advocate General Eleanor Sharpston of 18 October 2012, case C-396/11 Ministerul Public - Parchetul de pe lângă Curtea de Apel Constanţa v Ciprian Vasile Radu, ECLI:EU:C:2012:648, § 70 et seq., 74 et seq.

48 Ibid. § 82. 
however, leaves many questions unanswered. First of all, it is not entirely clear how the test proposed by the CJEU should be proved and who bears the burden of proof. Sometimes it might be very difficult to present sufficient evidence that the entire detention system is inefficient. Another concern regards possible forum shopping to achieve impunity in cases where detention conditions have not been improved in a reasonable time. Problems regarding detention conditions cannot be solved easily and fast. Perhaps in the future this judgment will trigger a legislative initiative for minimum EU detention standards which was suggested by Advocate General Y. Bot in his opinion. ${ }^{49}$

\section{The Case Law of the ECtHR and the BVerfG}

The case-law of the CJEU underlines the importance of mutual trust in cooperation within the EU, especially in the Area of Freedom, Security and Justice. Having analysed the reasoning of the CJEU, it is worth taking a closer look at the judgment of the BVerfG in a case related to the European Arrest Warrant (Order of 15 December 2015 EAW II).$^{50}$ Already, the past rulings of this court, such as the 'Solange' jurisprudence, have become model solutions, discussed and applied across Europe and beyond. ${ }^{51}$

The case concerned the surrender of an American citizen from Germany to Italy under the EAW. It was issued for the purpose of executing a sentence imposed in Italy after trial in absentia. The German court had serious doubts about the procedural guarantees in Italy, and therefore asked the relevant Italian authorities for the necessary information regarding national law. The German court tried to determine what kind of remedies the accused was entitled to and what provisions would apply in the case of a trial during which the accused were not present. After the necessary information was provided, referring among other things to the principle of mutual trust and obligations set out in the FD EAW, the Düsseldorf Higher Regional Court stated that extradition in this case was lawful. This decision was appealed in the BVerfG, which found that executing the arrest warrant was contrary to the German legal order. The Court referred primarily to the constitutional aspects of criminal sentences, stating that in this case executing the Framework Decision on the European arrest warrant affects the principle of individual guilt, and thus the principle of the rule of law, and this forms part of the inalienable constitutional identity under the Basic Law (i.e. German Constitution). The Court also referred to the ECHR where the presence of the defence - be it in the initial proceed-

49 Opinion of Advocate Generaln Yves Bot of 3 March 2016, joined cases C-404/15 and C-659/15 PPU Aranyosi and Căldăraru, ECLI:EU:C:2016:140.

50 Order of BVerfG of 15 December 2015 in case no. 2 BvR 2735/14.

51 T. Reinsbracher, M. Wendel, The Bundesverfassungsgericht's European Arrest Warrant II Decision, in "Maastricht Journal of European and Comparative Law" 2016, vol. 23, p. 702. 
ings or upon retrial - is one of the essential requirements under Art. 6 ECHR (the right to a fair trial). BVerfG stressed that Italian procedural law, in the described case, did not provide the accused with the undeniable guarantee that he would have an opportunity to have a new hearing of evidence at the appeal stage. It found that the requested person who had been sentenced in his or her absence and who had not been informed about the trial and its conclusion should at least have been provided with the real opportunity to defend himself or herself effectively after having learned of the trial, in particular by presenting circumstances to the court that may exonerate himself or herself and by having them reviewed. The Italian criminal proceedings failed to ensure such standards at that time. In the opinion of the BVerfG, the Higher Regional Court failed to sufficiently follow up on that issue. It contented itself with finding that a hearing of evidence in Italy was 'in any case not impossible'. On these grounds, the BVerfG stated that the Italian criminal proceedings were not in compliance with the minimum guarantees laid down in the German Constitution. The key aspect of the judgement is a reference to the so called Identity Review Order (Identitätskontrolle), which is a review of the conformity of the standards of legal proceedings in the issuing state with the German national order. Under this principle, even if the procedure in the issuing state meets the EU standards, it still needs to abide by the key German constitutional standards. These standards could not be met in a situation where the accused, after his surrender to Italy, was not provided with a legal remedy with which he could have challenged the sentence rendered in his absence in a manner that safeguarded his rights of defence. Such rights under the German constitution are inalienable and encompassed by the guarantee of human dignity.

Thereby, the BVerfG stated that the order of the Düsseldorf Higher Regional Court violated the fundamental rights of the accused in the main case under the Basic Law (Constitution) insofar as it declared the extradition under the EWA permissible. It recognized that the principle of mutual trust and the effectiveness of EU law must give way to the protection of fundamental rights guaranteed by the Constitution. ${ }^{52}$ The justification for such a position was that the Member States were the 'masters of the Treaties', and that the validity and the primacy of Union law depends on their will. National law, therefore, in such cases limits the principle of the supremacy of EU law. In the Court's opinion: "In general, sovereign acts of the European Union and acts of German public authority - to the extent that they are determined by Union law - are, due to the prece-

52 Cf. N. Gazeas, Die Europäische Beweisanordnung - Ein weiterer Schritt in die falsche Richtung?, in: "Zeitschrift für Rechtspolitik" 2005, no. 1, p. 19, which indicates that the German parliament, when adopting the Council Framework Decision 2008/978/JHA of 18 December 2008 on the European evidence warrant for the purpose of obtaining objects, documents and data for use in proceedings in criminal matters (Official Journal L 350/72 of 30 December 2008), proposed that due to the large differences between the criminal law systems in the Member States and the insufficient level of procedural guarantees in the Union, mutual recognition cannot take place automatically and without any limitations. 
dence of application of European Union Law, not to be measured against the standard of the fundamental rights enshrined in the Basic Law. However, the precedence of application of European Union Law is limited by the constitutional principles that are beyond the reach of European integration".

The position of the German court underlines the conditionality of the principle of mutual trust. Regardless of considerations concerning, among other things, the principle of loyalty, the ruling of the German Constitutional Court is an example of a restrained approach to the principle of mutual trust. ${ }^{53}$

Another decision which sets the way for the interpretation of the principle of mutual trust is the judgment of the ECtHR in the case of Avotinš v. Lithuania. ${ }^{54}$ In this case, the ECtHR examined the compliance of the enforcement of the foreign judgement under the Regulation 44/2001 on jurisdiction and the recognition and enforcement of judgments in civil and commercial matters (known as 'Brussels $I$ ) with the ECHR. In this case, the ECtHR had, for the first time, to examine observance of the guarantees of a fair hearing in the context of mutual recognition in civil and commercial matters based on European Union law. Considering the scope of EU judicial cooperation it was only a matter of time before the ECtHR had to rule on the issue $\mathrm{e}^{55}$ as it was predictable that the mutual recognition and enforcement of civil judgments can interfere with fundamental rights in many different ways.

The case concerned a judgment of a Cypriot court ordering the applicant to pay a debt he had contracted with a Cypriot company, and an order made by the Latvian courts for the enforcement of the Cypriot judgment in Latvia. It is also worth noting at the outset that this case also concerns a judgment that was rendered in absentia (in this case in the absence of the defendant). In the applicant's opinion, the Lithuanian court violated Article 6 of the ECHR (the right to a fair trial), due to the fact that it had authorised the

53 The judgment was called 'Solange III', due to its bold claims against the priority of EU law and the system of protection of fundamental rights created within it. Cf. H. Satzger, Grund-und menschenrechtliche Grenzen für die Vollstreckung eines Europäischen Haftbefehls? - „Verfassungsgerichtliche Identitätskontrolle" durch das BVerfG vs. Vollstreckungsaufschub bei „außergerwöhnlichen Umständen“ nach dem EuGH, „Neue Zeitschrift für Strafrecht“2016, no. 9, pp. 514-522.

54 Judgment of ECtHR of 23 may 2016 in case Avotinš̌ v. Lithuania (no. 17502/07). Council Regulation (EC) No 44/2001 of 22 December 2000 on jurisdiction and the recognition and enforcement of judgments in civil and commercial matters (Official Journal L 12/1 of 16 January 2001). See also S. Ø. Johansen, EU law and the ECHR: the Bosphorus presumption is still alive and kicking - the case of Avotinš v. Latvia, http://eulawanalysis.blogspot.com/2016/05/eu-lawand-echr-bosphorus-presumption.html [access: 14.01.2018].

55 Cf. e. g.: in the case Pietro Pianese v. Italy and the Netherlands (no. 14929/08), an Italian citizen complained about detention based on the EAW, alleging violations of Art. 5 of the Convention. However, the ECtHR declared the applicant's allegations inadmissible, because they were brought out of time and were manifestly ill-founded. In turn, in case Romeo Castaño v. Belgium (no. 8351/17), the ECtHR will check compliance the refusal to enforce EAW with the Convention. 
enforcement of the Cypriot judgment, although the decision had been delivered in breach of his defence rights and had thus been clearly unlawful.

The ECtHR held that there was no violation of Article 6 of the ECHR. The applicant could have used the remedies available under Cypriot law. His inaction and lack of diligence contributed to the situation to a large extent and he could have prevented it. The defendant signed the acknowledgment of debt deed, which contained a clause conferring jurisdiction to the Cypriot courts. He should have been aware of the consequences of his actions and the possibility that the creditor would institute proceedings in this country. Regardless of the above and more than the ruling itself, in this particular case what is more interesting for us are the general observations of the court on the delicate issue of application of EU law on the one hand and respect for fundamental rights envisaged in ECtHR on the other.

Although the ECtHR did not notice any infringement of the ECHR, it pointed out that it is impossible to introduce a mechanical and automatic recognition system within the EU without providing the Member States with the opportunity to check the equivalence of the protection of fundamental rights. ${ }^{56}$ The ECtHR reiterated that, when applying European Union law, States are bound by the obligations they entered into on acceding to the ECHR. These obligations must be assessed in the light of the presumption established by the Court in the famous 'Bosphorus' judgment. ${ }^{57}$ This judgment introduced the presumption of equivalent protection of ECHR rights by the EU. However, "any such presumption can be rebutted if, in the circumstances of a particular case, it is considered that the protection of Convention rights was manifestly deficient" ${ }^{8}$ The ECtHR stated that member states of an international organization are still liable under the ECHR for all acts and omissions of its organs regardless of whether the act or omission was a consequence of the necessity to comply with international legal obligations. In other words, the mere fact that a given Member State is applying EU law and executing a judgment issued by another EU Member State does not negate its obligation to check whether ECHR standards were met.

In the Avotins case, the ECtHR confirmed that the Bosphorus presumption also applies to the mutual recognition mechanism. The Court observed, however, that this presumption is applicable only when two conditions are met. First, if there is an 'absence of any margin of manoeuvre' on the part of the domestic courts and the deployment of the full potential of the supervisory mechanism provided for by European Union law. In Avotins these conditions were fulfilled, as the Brussels I Regulation (as opposed to directives) is directly applicable and contains only limited grounds for refusal (applicable in marginal situa-

56 Cf. S. Ø. Johansen, op. cit.

57 Judgement of ECtHR of 30 June 2005 in case Bosphorus Hava Yolları Turizm ve Ticaret Anonim Sirketi v. Ireland (no. 45036/98).

58 Cf. Bosphorus Hava Yolları Turizm ve Ticaret Anonim Şirketi v. Ireland. 
tions). According to the ECtHR, the Latvian courts did not have, therefore, any margin of manoeuvre in this case (which might be questioned as EU law does not regulate, for example, such matters as burden of proof with regard to fundamental rights observance which could arguably give some leeway to the executing court $)^{59}$. With regard to the second condition, the ECtHR held that it was met in this case since Mr Avotins had not advanced any specific argument concerning the interpretation of the Brussels I Regulation and its compatibility with fundamental rights. Especially so, as there was no request that a preliminary ruling should have been sought from the CJEU. The passive attitude of the defendant with respect to his rights and legal actions supports the statement that the second condition was also met.

However, the mere finding that all the above-mentioned conditions have been met is not yet sufficient. Another important aspect that the executing court must take into account while recognising a foreign judgment is whether the protection of ECtHR rights in the entire procedure is not 'manifestly deficient'. The ECtHR has very clearly explained that obligation: "The Court must satisfy itself $[. .$.$] that the mutual recognition$ mechanisms do not leave any gap or particular situation which would render the protection of the human rights guaranteed by the Convention manifestly deficient. In doing so it takes into account, in a spirit of complementarity, the manner in which these mechanisms operate and in particular the aim of effectiveness which they pursue. Nevertheless, it must verify that the principle of mutual recognition is not applied automatically and mechanically [...] to the detriment of fundamental rights - which, the CJEU has also stressed, must be observed in this context [...]. In this spirit, where the courts of a State which is both a Contracting Party to the Convention and a Member State of the European Union are called upon to apply a mutual recognition mechanism established by EU law, they must give full effect to that mechanism where the protection of Convention rights cannot be considered manifestly deficient".

How should this be interpreted in the light of the principle of mutual trust? Convincingly, the aspirations of absolute mutual trust have been negatively assessed. ${ }^{60}$ Obviously, the system of simplifying the migration of judgments in the EU has not been denied. The ECtHR did not undermine the basis of the simplified mechanism for the recognition and enforcement of judgments, in particular the introduction of a prohibition on reviewing foreign judgements as to their substance in the Member State in which recognition/enforcement is sought (the prohibition of révision au fond). However, according to the ECtHR, Member States must be able to investigate whether the proceedings in

59 Cf. S. Ø. Johansen, op. cit.

60 G. Biagioni, The Uneasy Balance Between Mutual Recognition of Judgments and Protection of Fundamental Rights, in "European Papers" 2016, Vol. 1, no. 2, p. 594, http://www.europeanpapers.eu/fr/system/files/pdf_version/EP_EF_2016_I_036_Giacomo_Biagioni_1.pdf [access: 12.01.2018]. 
the issuing State do not violate the standards of the ECHR, even if this is not provided for in EU law. ${ }^{61}$ At the same time, it was emphasized that the level of protection of fundamental rights introduced by EU law cannot interfere with guarantees provided at the international level. The judgement of the ECtHR is clearly a signal for a revision of some of the legal features of EU judicial cooperation, and arguably not only in judicial cooperation in civil matters.

\section{Conclusions}

The principle of mutual trust is often referred to in case-law and probably this trend will not change in the near future given that the presumption of trust is the basis for all mutual recognition instruments. Therefore, there is a need to clarify what the principle of mutual trust means exactly and how it is understood by courts. The decisions referred to in this paper have explained, at least to a certain extent, the content of the principle. Moreover, they have provided an example of the complex relationship between mutual trust, fundamental rights protections, mutual recognition and the enforcement of judgments. Although the judgments relate to different aspects of cooperation and were issued in different circumstances, in our opinion some general conclusions can be drawn. Firstly, courts seem more and more often to refer to the principle of mutual trust in the Area of Freedom, Security and Justice in their reasoning. The intensification of the reference to the mutual trust principle goes hand in hand, however, with the belief that the principle has certain limits. It is clear now that the presumption of mutual trust under certain circumstances is rebuttable. The common feature of all judgments is the negation of the absolute nature of the principle of mutual trust. The conditional nature of the principle of mutual trust stems from, among other things, the need for fundamental rights protection. ${ }^{6}$

Secondly, the basis of the principle's restriction is something which fundamentally differentiates the CJEU, BVerfG and ECthR. Where the ECtHR indicates that the minimum protection level should respond to the standard envisaged in the ECHR, the BVefG recognizes as a priority the standards set by the German Constitution which cannot be reduced due to the abstract principle of trust. The CJEU refers to guarantees referred to directly in EU instruments. In Melloni, the CJEU for the first time set a minimum

61 Ibid, p. 589.

62 Unfortunately, in the Union there are still serious deficiencies in the protection of fundamental rights. For example, due to bad conditions in prisons in Bulgaria, the German courts refused extradition to that country several times, information available at:http://www.euractiv.com/ section/justice-homeaffairs/news/German-courts-refuse-to-extradite-prisoners-to-bulgaria/ [access: 12.01.2018]. 
of fundamental rights protection in criminal matters by reference to the European ordre public. The CJEU tried to create a common standard, a public order category which takes into account European requirements, and not only the characteristics of the national legal order. This means that the interpretation of the conditions for the recognition and enforcement of judgments may also be influenced by factors not directly indicated in the act (i.e. the principle of protection of fundamental rights).

Adoption of mutual trust as the basis for integration, and above all the mechanisms for recognition and enforcement of judgments is an ambitious project. Its content, however, must take into account the context and the conditions in which it operates - the aims of the regulations, but also the attitude of the national courts. Referred judgments make it clear that there are different approaches to the principle of mutual trust. Practice will show which point of view becomes the leading one, especially as the presumption of adequate protection of fundamental rights and the rule of law in all Member States is becoming increasingly questionable since the Commission took the unprecedented step of triggering the formal steps established in Article 7 of Treaty on the European Union ${ }^{63}$ against Poland. The former convictions that in this Union of values it will not be necessary to apply penalties pursuant to Article 7 of the Union Treaty ${ }^{64}$ unfortunately turned out to be too optimistic.

\section{Literature}

Biagioni G., The Uneasy Balance Between Mutual Recognition of Judgments and Protection of Fundamental Rights, "European Papers" 2016, vol. 1, no. 2, p. 594, http://www. europeanpapers.eu/fr/system/files/pdf_version/EP_EF_2016_I_036_Giacomo_Biagioni_1.pdf [access: 12.01.2018].

Douglass-Scott S., Opinion 2/13 on EU accession to the ECHR: a Christmas bombshell from the European Court of Justice, http://verfassungsblog.de/opinion-213-eu-accessionechr-christmas-bombshell-european-court-justice-2/\#.VRGRofmG9uw [access: 11.01.2018].

Gazeas N., Die Europäische Beweisanordnung - Ein weiterer Schritt in die falsche Richtung?, "Zeitschrift für Rechtspolitik " 2005, no. 1

Gáspár-Szilágyi S., Joined Cases Aranyosi and Căldăraru: Converging Human Rights Standards, Mutual Trust and a New Ground for Postponing a European Arrest Warrant, "European Journal of Crime, Criminal Law and Criminal Justice” 2016, vol. 24, no. 2-3.

63 Treaty on European Union as amended by the Treaty of Lisbon - Official Journal of the European Union, C 83/13 of 30.3.2010.

64 Communication from the Commission to the Council and the European Parliament of 15.10.2003 on article 7 of the Treaty on European Union, COM (2003) 606 final, p. 12. 
Geyer F., European Arrest Warrant: Advocaten voor de Wereld VZW v. Leden van de Ministerraad, "European Constitutional Law Review" 2008, no. 4, p. 161.

Gragl P., The Accession of the European Union to the European Convention on Human Rights, Oxford and Portland, OR 2013.

Guild E., Martin L. (Ed), Still not resolved? Constitutional Issues of the European Arrest Warrant: a Look at Challenges Ahead after the Lessons Learned from the Pasty, https:// www.utwente.n1/en/bms/pa/staff/marin/Still\%20not\%20resolved\%20Constitutional\%20Challenges\%20to\%20the\%20European\%20Arrest\%20Warrant.pdf [access: 02.01.2018].

Janssens C., The principle of mutual recognition in EU law, New York 2013.

Johansen S. Ø., EU law and the ECHR: the Bosphorus presumption is still alive and kicking - the case of Avotinš v. Latvia, http://eulawanalysis.blogspot.com/2016/05/eu-lawand-echr-bosphorus-presumption.html [acces: 14.01.2018].

Klimek L., Mutual recognition of Judicial Decisions in European Criminal Law, Bratislava 2017.

Lenaerts K., La Vie Après L'avis: Exploring the Principle of Mutual (Yet Not Blind) Trust, Common Market Law Review, 2017, no. 54.

Idem, The principle of mutual recognition in the area of freedom, security and justice, the fourth annual lecture at All Souls College, University of Oxford, 30 January 2015, https://www.law.ox.ac.uk/sites/files/oxlaw/the_principle_of_mutual_recognition_in_ the_area_of_freedom_judge_lenaerts.pdf, [access: 22.12.2017].

Mitsilegas V., The Limits of Mutual Trust in Europe's Area of Freedom, Security and Justice: From Automatic Inter-State Cooperation to the Slow Emergence of the Individual, "Yearbook of European Law" 2012, no. 31.

Ostropolski T., The CJEU as a Defender of Mutual Trust, "New Journal of European Criminal Law" 2015 v. 6.

Peers S., EU Justice and Home Affairs Law, 4th ed. Volume 2: EU Criminal Law, Policing and Civil Law, Oxford 2016.

Idem, Court of Justice: The NS and ME Opinions - The Death of "Mutual Trust"?, Statewatch Analysis, http://www.statewatch.org/analyses/no-148-dublin-mutual-trust.pdf [access: 15.12 .2017$]$.

Reinsbracher T., Wendel M., The Bundesverfassungsgericht's European Arrest Warrant II Decision, "Maastricht Journal of European and Comparative Law" 2016, vol. 23.

Reitemeyer S., Pirker B., Opinion 2/13 of the court of justice on access of the EU to the ECHR - one step ahead and two steps back, http://europeanlawblog.eu/2015/03/31/ opinion-213-of-the-court-of-justice-on-access-of-the-eu-to-the-echr-one-stepahead-and-two-steps-back/ [access: 21.12.2017].

Satzger H., Grund - und menschenrechtliche Grenzen für die Vollstreckung eines Europäischen Haftbefehls? - „Verfassungsgerichtliche Identitätskontrolle“ durch das BVerfG vs. Vollstreck- 
ungsaufschub bei „außergewö̈hnlichen Umständen“ nach dem EuGH, „Neue Zeitschrift für Strafrecht" 2016, no. 9

Willems A., Mutual Trust as a term of art in EU Criminal Law: Revealing its hybrid character, European Journal of Legal Studies 2016, vol. 9.

Vermeulen G., De Bondt W., Ryckman C.(eds.), Rethinking international cooperation in criminal matters. Moving beyond actors, bringing logic back, footed in reality, Antwerp 2012.

Charter of Fundamental Rights of the European Union (Official Journal C 326/391 of 26 October 2012).

Communication from the Commission to the Council and the European Parliament Mutual recognition of Final Decisions in criminal matters /COM/2000/0495 final/.

Convention on the Punishment of Road Traffic Offences of 30 November 1964, European Treaty Series no. 052 [1964].

Council Framework Decision 2002/584/JHA of 13 June 2002 on the European arrest warrant and the surrender procedures between Member States as amended by the Framework Decision 2009/299/JHA (Official Journal L 190/1 of 18 July 2002).

Council Framework Decision 2008/909/JHA of 27 November 2008 on the application of the principle of mutual recognition to judgments in criminal matters imposing custodial sentences or measures involving deprivation of liberty for the purpose of their enforcement in the European Union (Official Journal L 327/27 of 5 December 2008).

Council Framework Decision 2008/978/JHA of 18 December 2008 on the European evidence warrant for the purpose of obtaining objects, documents and data for use in proceedings in criminal matters (Official Journal L 350/72 of 30 December 2008).

Council Framework Decision 2009/299/JHA of 26 February 2009 amending by the Framework Decisions 2002/584/JHA, 2005/214/JHA, 2006/783/JHA, 2008/909/ JHA and 2008/947/JHA, thereby enhancing the procedural rights of persons and fostering the application of the principle of mutual recognition to decisions rendered in the absence of the person concerned at the trial (Official Journal L 81/14 of 27 March 2009).

Council Regulation(EC) No 44/2001 of 22 December 2000 on jurisdiction and the recognition and enforcement of judgments in civil and commercial matters (Official Journal L 12/1 of 16 January 2001).

Council Regulation (EC) No 343/2003 of 18 February 2003 establishing the criteria and mechanisms for determining the Member State responsible for examining an asylum application lodged in one of the Member States by a third-country national (Official Journal L 50/1 of 25 February 2003).

Directive 2014/41/EU of the European Parliament and of the Council of 3 April 2014 regarding the European investigation order in criminal matters (Official Journal L 130/1 of 1 May 2014). 
Presidency Conclusions, Tampere European Council 15 and 16 October 1999, http:// www.europarl.europa.eu/summits/tam_en.htm [access: 17.01.2018].

Programme of measures to implement the principle of mutual recognition of decisions in criminal matters (Official Journal L C 12/10 of 15 January 2001).

\section{SUMMARY}

\section{The Principle of Mutual Trust in the Area of Freedom, Security and Justice. analysis of Selected Case Law}

The paper concerns the principle of mutual trust and its interpretation by the Court of Justice of the European Union as well as two other important European courts: the European Court of Human Rights and the German Constitutional Court. The paper presents the important change of direction in interpretation of the principle of mutual trust by the CJEU. Initially, the belief in the existence of mutual trust between member states was firm. Over time, however, it has turned out that even in the EU - which follows from a number of judgments of the ECtHR - violations of human rights sometimes happen. This dramatically undermines trust in foreign judicial systems. This led the CJEU to the conclusion that the principle of mutual trust is rebuttable and that in some circumstances limitations to the principles of mutual recognition and mutual trust can be made. This conclusion can be treated as an answer in the specific 'judicial dialogue' of the CJEU with the ECtHR and the German Constitutional Court - the two latter courts seemed to notice earlier that mutual trust between member states cannot be blind and unconditional.

Keywords: European criminal law, Area of Freedom, Security and Justice, principle of mutual trust, mutual recognition

Oskar Losy, Adam Mickiewicz University Poznań, Faculty of Law and Administration, Al. Niepodległości 53, 61-714 Poznań, Republic of Poland, e-mail: oskar.losy@amu.edu.pl. Anna Podolska, University of Gdańsk, Faculty of Law and Administration, ul. Jana Bażyńskiego 6, 80-980 Gdańsk, Republic of Poland, e-mail: a.podolska@prawo.ug.edu.pl. 